\title{
AN ANALYSIS OF MISCONCEPTIONS COVERED IN THE 12TH GRADE CHEMISTRY TEXTBOOKS OF REDOX AND ELECTROCHEMISTRY
}

\author{
A. Nurraudah, V. H. Elfi Susanti and M. Masykuri \\ Chemistry Education Department, Faculty of Teacher Training and Education, Sebelas Maret University, \\ Surakarta, Indonesia
}

\begin{abstract}
Despite its important role in science education as major reference supporting teaching and learning activities at schools, there have not been many researches focusing on investigating the quality of science textbook content. Science subjects, such as chemistry, are way more susceptible to errors because the need of more analysis and deduction activities rather than mere information gathering. This present, descriptive study examined the presence of misconceptions in the 12th grade chemistry textbooks on Redox and Electrochemistry. Each textbook was examined page by page based on document analysis method. The research samples consist of 2 textbooks obtained through purposive sampling. The founded misconceptions divided into 5 categories: oversimplifications, overgeneralizations, obsolete concepts and terms, misidentifications, and flawed research. The results showed that there are 13 misconceptions found in textbooks, namely: $7.7 \%$ oversimplifications, $30.8 \%$ overgeneralization and $61.5 \%$ misidentifications. Based on the analysis, misidentifications are the most common misconceptions found both in book A and book B. These findings may provide a platform to improve the quality of textbooks preparation in particular and education in general.
\end{abstract}

Keywords: misconceptions; document analysis; 12 th grade chemistry; science textbooks

\section{Introduction}

Textbooks are the main reference source in supporting teaching and learning process in schools (Chiappetta and Filman, 2007; Mahmood, 2011; King, 2010; Stinner, 1992; Odom, 1993; Chiang-Soong and Yager, 1993; Adisendjaja, 2007). For teachers, textbooks are considered necessary to support the academic competencies when delivering materials, while for students, the need to have a textbook is considered very important to help them understand the material as well as to support the self-learning process at home. In a survey conducted by the Council for Science and Technology in 2000 stated that 89 of a total of 586 junior high school teachers "often" used textbooks during the teaching and learning process in the classroom (King, 2010). In addition, most science teachers also make $75 \%$ or more of the material in the textbook as the main guideline in conducting the teaching process where more than $90 \%$ of the classes use the same textbook (Weiss, 1987).

The high level of dependence from teachers and students on the textbooks requires all of the explanations of the concepts written in them have to be true. The process of publishing a textbook is not easy either. The textbooks must go through a series of selection stages conducted by BSNP (National Education Standards Council) before 
finally circulating in the community. However, the problem arises when these 'trusted' textbooks are one of the main factors why misconception happened in the first place (Suparno, 2005).

Misconceptions are defined as misunderstandings or misunderstandings where concepts that are considered true actually contradict the theories and opinions of experts who have been universally accepted. Misconceptions caused by teachers and textbooks are known as "didaktikogenic misconceptions". This misconception is more often found in the field of science because of its nature which requires more of analysis process and deduction than just information gathering activities (Chattopadhyay, 2016). The publications about misconceptions in chemistry as the main focus of research are relatively new compared to physical and biological material that has been more intensively studied (Nakhleh, 1992). Chemistry itself has generally abstract and structural concepts with very rapid theoretical progress (Winarni, 2010).

A study conducted by Purwitasari (2012) found that there were misconceptions in the BSE book by Ari Harnanto and Ruminten in the matter of Mass Conservation Law and Permanent Comparative Law of 40\% and $27 \%$ in Chemical Calculations on Molar Mass and Molecular Formulas. In addition, Sari, et al. (2015) found seven terms that could potentially lead to misconceptions in Chemical Equilibrium material, namely: (1) equilibrium, (2) dynamic, (3) concentration, (4) endotherm, (5) contact process, (6) phase, and (7) reaction. Whereas, Barke et al. (2009) stated that misconceptions in chemistry often occur in Chemical Equilibrium, Acid-Base Reactions, Complex Compounds, Energy, and Redox and Electrochemistry.

Redox and Electrochemistry is a material that is quite complex and difficult to understand (Barke et.al. 2009). Sanger and Greenbowe (1999) found a total of 32 types of misconceptions that students often make regarding Volta cells, Electrolysis cells and Nernst equations. In addition to the high level of complexity, this material is also structural in nature where in class $\mathrm{X}$ there is prerequisite material, namely Oxidation-Reduction Reactions, which is closely related to this material. The existence of the prerequisite material requires students to truly understand the material in question very well. This is what causes misconceptions in Redox and Electrochemistry is very difficult to avoid.

Based on the background explanation above, textbook as one of the most important teaching materials needs to be analyzed its contents from a contextual point of view, where existing misconceptions are grouped into 5 different categories, such as: oversimplications, overgeneralizations, obsolete concepts and terms, misidentifications, and flawed researched (Hershey, 2004). The results of chemical textbooks analysis in Redox and Electrochemistry are expected to be useful for teachers, students, book writers, and also policy makers in education.

Methodology

This study uses a qualitative descriptive approach where researchers seek a conclusion by analyzing data qualitatively in order to describe a particular phenomenon (Creswell, 2014). The qualitative descriptive approach in this study was used to analyze the misconceptions in 12th grade Redox and Electrochemistry concepts in two chemistry textbooks which were examined in a narrative and descriptive manner.

\section{Textbooks}

In this study, two 12th grade high school chemical textbooks were used. The object retrieval technique in this study is based on purposive sampling technique, which is a non-random sampling technique where the researchers determine their own sample for certain reasons so that the existing problems could be answered (Creswell, 2014). The taking of the 12th grade high school chemistry textbooks as the research objects were based on the consideration that these textbooks have passed the standardization process by BNSP and the two research objects are the most commonly used textbooks by teachers and students of SMA N 2 Karanganyar during the observation process. Meanwhile, the concept analysis of Redox and Electrochemistry was chosen 
based on the level of difficulty and the risk of high misconception (Barke et. al, 2009; Sangger and Greenbowe, 1999).

Table 1 Description of 12th grade chemistry textbooks used in the study.

\begin{tabular}{lll}
\hline Label of the textbook & Author & Language \\
\hline Book A & Unggul Soedarmo & Indonesia \\
Book B & Sentot Budi Rahardjo & Indonesia \\
\hline
\end{tabular}

Data Collection and Analysis

In this study, document study was used as a research method. The study of documents or texts is a study that focuses on the analysis or interpretation of written materials such as textbooks, newspapers, magazines, films, texts, and articles based on the context (Arifin, 2013). This method is carried out by the process of reading textbooks carefully, page by page, in each sub-chapter contained in Redox and Electrochemistry of the two research objects, to obtain the wrong concept statement (misconception) in the text. All misconceptions found in the textbook are then marked and classified into 5 categories, namely: oversimplications, overgeneralizations, obsolete concepts and terms, misidentifications, and flawed research (Hershey, 2004). The data from the misconceptions that have been previously analyzed by the researchers then submitted to two chemists who are competent in the field of chemistry and misconceptions to validate the results of the content analysis conducted by the researchers. This validation is carried out to obtain information related to chemical concepts in Redox and Electrochemistry so that they can be mapped where the right concepts and wrong concepts are located (misconceptions).

Result and Discussion

Result

Data from the analysis of the 12th grade high school chemistry textbooks were obtained through literature review and validation processes. The result of this analysis process would be grouped according to each category of misconceptions. The complete data on the number of misconceptions are presented in Table 2 below.

Table 2 Analysis of research objects based on the misconceptions category.

\begin{tabular}{cccccccc}
\hline No & Textbook & \multicolumn{7}{c}{ Misconceptions Category } \\
\cline { 3 - 8 } & & OS & OG & OCT & MI & RF & Total \\
1 & A & 1 & 1 & 0 & 5 & 0 & 7 \\
2 & B & 0 & 3 & 0 & 3 & 0 & 6 \\
& Total & 1 & 4 & 0 & 8 & 0 & 13 \\
& & $7.7 \%$ & $30.8 \%$ & $0 \%$ & $61.5 \%$ & $0 \%$ & $100 \%$ \\
\hline
\end{tabular}

Based on Table 2, it can be concluded that the category of misidentification is the type of misconception that occurs most in both book A and book B, while the obsolete concepts and terms and flawed research categories are not found in each research object.

Discussion

There are a total of 13 misconceptions that occur in the research objects. These misconceptions include these following subjects:

Oversimplications 
1. "Electrochemically, the iron bonding process is the event of oxidation of iron by oxygen coming from the air" (Book A, pp. 59). This statement experienced oversimplification because the factors that cause corrosion in iron is not only oxygen but also the presence of water in the form of moisture (Silberberg, 2010).

\section{Overgeneralizations}

1. "In general, corrosion is damage to metal objects due to environmental influences" (Book A, pp. 59). This misconception is included in the category of overgeneralization because the statement "due to environmental influences" has too broad meaning and not all environmental factors can cause the corrosion;

2. "In Volta cells or Galvani cells, a chemical reaction changes into electrical energy" (Book B, pp. 39). Theoretically, chemical reactions are generally divided into two types, namely spontaneous and nonspontaneous chemical reactions. Based on the explanation of the source book, in Volta's cell, a chemical reaction changes spontaneously $(G>0)$, whereas in this research object, it is not explicitly explained or written down in detail which types of chemical reactions occur in Volta cells;

3. "The salt bridge is a tube containing an electrolyte solution such as NaNO3 or K2SO4" (Book B, pp. 39). The statement contradicts to the standard concept because not all electrolyte solutions can be used as a solution in the salt bridge. Only inert electrolyte solutions (not reacting to other solutions and electrodes) can be used in the salt bridge;

4. "In electrolytic cells, there is a change in electrical energy into a chemical reaction" (Book B, pp. 39). Chemical reactions are divided into two, namely spontaneous and non-spontaneous chemical reactions. In the case of electrolytic cells, the chemical reaction that will be produced is a non-spontaneous chemical reaction. The author has counted for four times about the description of electrolysis cells in book B, but none of the sentences pertain to these non-spontaneous chemical reactions. This is very unfortunate because at the beginning of the chapter in the concept map, the book briefly illustrates the involvement of a non-spontaneous redox reaction in electrolysis cell.

\section{Misidentifications}

1. "The potential difference is written with the cell $\mathrm{E}^{\mathrm{o}}$ symbol and expressed in volts" (Book A, pp. 46). In book $\mathrm{A}$, the cell potential difference is written with the cell $\mathrm{E}^{\mathrm{o}}$ symbol. This one is included as misidentification because $\mathrm{E}^{\mathbf{o}}$ cell is a symbol for a standard electrode potential while the cell potential difference is supposed to be written without the superscript "o" ( expressing standard state conditions);

2. The Volta cell above can be written in cell notation (Book A, pp.46):

$$
\mathrm{Zn}\left|\mathrm{Cu}_{2}{ }^{+}(1.0 \mathrm{M}) \| \mathrm{Zn}_{2}{ }^{+}(1.0 \mathrm{M})\right| \mathrm{Cu} \mathrm{E} \text { cell }=+1.10 \mathrm{~V}
$$

(Anode) (Cathode)

Based on the source book, what is meant by the anode and cathode are only $\mathrm{Zn}$ (left end) and $\mathrm{Cu}$ (right end) elements. Incorrect identification occurs because the research object writes the anode and cathode information 
on a part involving a solution of $\mathrm{Zn}_{2}{ }^{+}$and $\mathrm{Cu}_{2}{ }^{+}$. The part on the left is two vertical lines (salt bridge), namely $\mathrm{Zn}_{(\mathrm{s})} \mid \mathrm{Cu}_{2}{ }^{+}$(aq) is referred to as half-cell oxidation (half-cell anode) while $\mathrm{Zn}_{2}{ }^{+}{ }_{(\mathrm{aq})} \mid \mathrm{Cu}$ (s) located to the right side of the salt bridge is called half-cell reduction (half-cathode cell);

3. $\quad$ Table 3 The standard electrode potential $\left(E^{o}\right)$ of multiple electrodes.

\begin{tabular}{|c|c|}
\hline Half-cell Reaction & $\mathrm{E}^{\circ}$ (volt) \\
\hline $\mathrm{Li}_{(\mathrm{aq})}^{+}+\hat{\mathrm{e}} \rightarrow \mathrm{Li}_{(\mathrm{s})}$ & -3.045 \\
\hline $\mathrm{K}_{(\mathrm{aq})}^{+}+\hat{\mathrm{e}} \rightarrow \mathrm{K}_{(\mathrm{s})}$ & -2.924 \\
\hline $\mathrm{Ba}^{2+}{ }_{(\mathrm{aq})}+\hat{\mathrm{e}} \rightarrow \mathrm{Ba}_{(\mathrm{s})}$ & -2.90 \\
\hline $\mathrm{Sr}^{2+}{ }_{(\mathrm{aq})}+\hat{\mathrm{e}} \rightarrow \mathrm{Sr}_{(\mathrm{s})}$ & -2.89 \\
\hline $\mathrm{Ca}^{2+}{ }_{(\mathrm{aq})}+\mathrm{e} \rightarrow \mathrm{Ca}_{(\mathrm{s})}$ & -2.76 \\
\hline $\mathrm{Na}^{+}(\mathrm{aq})+\dot{\mathrm{e}} \rightarrow \mathrm{Na}_{(\mathrm{s})}$ & -2.71 \\
\hline $\mathrm{Mg}^{2+}{ }_{(\mathrm{aq})}+\hat{\mathrm{e}} \rightarrow \mathrm{Mg}_{(\mathrm{s})}$ & -2.375 \\
\hline
\end{tabular}

(Book A, pp. 49)

Table 3 above has been misidentified because in the table of standard electrode potential values in book A use a one-way arrow indicating that the reaction goes irreversibly. This is very much contradict from Silberberg's explanation (2010: 719) which states that several important points regarding the potential concept of standard electrodes, one of which is the half-reaction process written using two-way arrows (equilibrium arrows) because the reaction in Volta cells can be reduced or oxidized (reversible).

4

\begin{tabular}{|c|c|c|}
\hline Anode & $: \mathrm{Fe}_{(\mathrm{s})} \rightarrow \mathrm{Fe}^{2+}{ }_{(\mathrm{aq})}+2 \mathrm{e}^{-}$ & $\mathrm{E}^{\circ}=+0.44 \mathrm{~V}$ \\
\hline Cathode & $: \mathrm{O}_{2(\mathrm{q})}+2 \mathrm{H}_{2} \mathrm{O}_{(\mathrm{l})+} 4 \mathrm{e}^{-} \rightarrow 4 \mathrm{OH}_{(\mathrm{aq})}^{-}$ & $E^{\circ}=+0.40 \mathrm{~V}$ \\
\hline
\end{tabular}

The cell reaction above experienced two types of misconceptions, such as:

- $\quad$ Error writing of the reaction equation in cathode section.

This error is included in the category of misidentification because book A records the reaction equation in cathode as $\mathrm{O}_{2(\mathrm{~g})}+2 \mathrm{H}_{2} \mathrm{O}_{(\mathrm{l})}+4 \mathrm{e}^{-} \rightarrow 4 \mathrm{OH}_{(\mathrm{aq})}^{-}$, whereas according to source book, the correct reaction is $\mathrm{O}_{2(\mathrm{~g})}+$ $4 \mathrm{H}^{+}{ }_{\text {(aq) }}+4 \mathrm{e}^{-} \rightarrow 2 \mathrm{H}_{2} \mathrm{O}_{(\mathrm{l})}$, where at the cathode there is an event of oxygen reduction into water (Chang, 2008).

- Calculation of the reaction $\mathrm{E}^{\mathbf{o}}$ value

The incorrect identification also occurs in the $\mathrm{E}^{\mathbf{o}}$ value of the reaction that originates from an error in writing the cathode reaction equation (domino effect). Book A clearly written that $0.84 \mathrm{~V}$ is the $\mathrm{E}^{\mathrm{o}}$ reaction value while based on the literature study, the $\mathrm{E}^{\circ}$ reaction value should be $1.67 \mathrm{~V}$.

5. Cell Notation (Book B, pp. 40): 


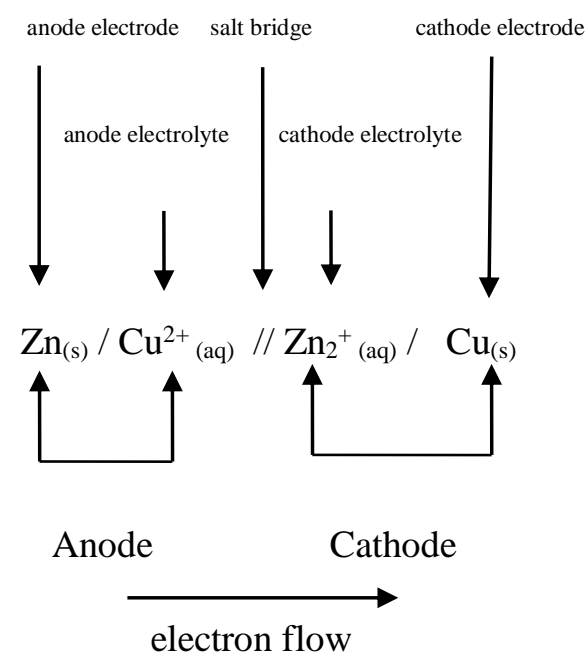

The cell notation concept above experienced two types of misconceptions, namely:

- In the cell notation writing section, it is stated that the entire section located on the left side of the salt bridge $\left(\mathrm{Zn}_{(\mathrm{s})}\right.$ and $\left.\mathrm{Cu}_{2}{ }^{+}{ }_{(\mathrm{aq})}\right)$ is an anode while all parts are located on the right side of the salt bridge $\left(\mathrm{Zn}_{2}{ }^{+}\right.$(aq) and $\left.\mathrm{Cu}_{(\mathrm{s})}\right)$ is cathode (misidentification). This is not, in accordance with the explanation of the source book, where the part in question is a half-oxidation reaction compartment (left) and a half-reaction reduction compartment (right), while only anode and cathode is meant for $\mathrm{Zn}$ and $\mathrm{Cu}$ elements respectively each acts as an electrode;

- In the source book, the salt bridge is symbolized by a double perpendicular line while the salt bridge in the research object is symbolized by a double slash. This is included in the category of misidentification because the rules in writing cell notation are a convention that has been determined by IUPAC so that scientifically, it was considered wrong.

6. Table 4 The standard reduction potential $\left(E^{\circ}\right)$ at $25^{\circ} \mathrm{C}$.

\begin{tabular}{|c|c|c|}
\hline Electrode & Half-cell & $\overline{\mathrm{E}^{\circ} \text { (volt) }}$ \\
\hline $\mathrm{Li}^{+} / \mathrm{Li}$ & $\mathrm{Li}_{(\mathrm{aq})}^{+}+\stackrel{e}{\mathrm{e}} \rightarrow \mathrm{Li}_{(\mathrm{s})}$ & -3.04 \\
\hline $\mathrm{K}^{+} / \mathrm{K}$ & $\mathrm{K}_{(\mathrm{aq})}^{+}+\dot{e} \rightarrow \mathrm{K}_{(\mathrm{s})}$ & -2.93 \\
\hline $\mathrm{Ba}^{2+} / \mathrm{Ba}$ & $\mathrm{Ba}_{(\mathrm{aq})}^{2+}+\hat{\mathrm{e}} \rightarrow \mathrm{Ba}_{(\mathrm{s})}$ & -2.92 \\
\hline $\mathrm{Ca}^{2+} / \mathrm{Ca}$ & $\mathrm{Ca}^{2+}{ }_{(\mathrm{aq})}+\hat{\mathrm{e}} \rightarrow \mathrm{Ca}_{(\mathrm{s})}$ & -2.84 \\
\hline $\mathrm{Na}^{+} / \mathrm{Na}$ & $\mathrm{Na}_{(\mathrm{aq})}^{+}+\hat{\mathrm{e}} \rightarrow \mathrm{Na}_{(\mathrm{s})}$ & -2.71 \\
\hline $\mathrm{Mg}^{2+} / \mathrm{Mg}$ & $\mathrm{Mg}^{2+}{ }_{(\mathrm{aq})}+\stackrel{\mathrm{e}}{\mathrm{e}} \rightarrow \mathrm{Mg}_{(\mathrm{s})}$ & -2.36 \\
\hline $\mathrm{Al}^{3+} / \mathrm{Al}$ & $\mathrm{Al}^{3+}{ }_{(\mathrm{aq})}+\mathrm{e} \rightarrow \mathrm{Mg}_{(\mathrm{s})}$ & -1.66 \\
\hline
\end{tabular}

(Book B, pp.42)

Table 4 above has been misidentified because the standard electrode potential values of book B use a one-way arrow indicating the reaction goes irreversibly. This is different from Silberberg's explanation (2010: 719) which states several important points towards the standard electrode potential, one of which is the half-reaction process written using two-way arrows (equilibrium arrows) because the reaction in Volta cells can be reduced or oxidized. 
The results of the misconception analysis that has been clearly described previously state that there are a total of 13 misconceptions found in book A and book B. Among the thirteen errors mentioned above, there is a pattern of misconceptions that are repeated in each research object (see Table 5).

Table 5 The similiarity of misconceptions in book A and book B.

\begin{tabular}{llc}
\hline & \multicolumn{1}{c}{ Misconception in- } & Misconception Category \\
\cline { 2 - 3 } $\begin{array}{c}\text { Research objects (book } \\
\text { A and book B) }\end{array}$ & The description of the cathode and anode in cell & Misidentification \\
& The symbol of $\mathrm{E}^{\circ}$ value in the electrode & Misidentification \\
& potential table & \\
\hline
\end{tabular}




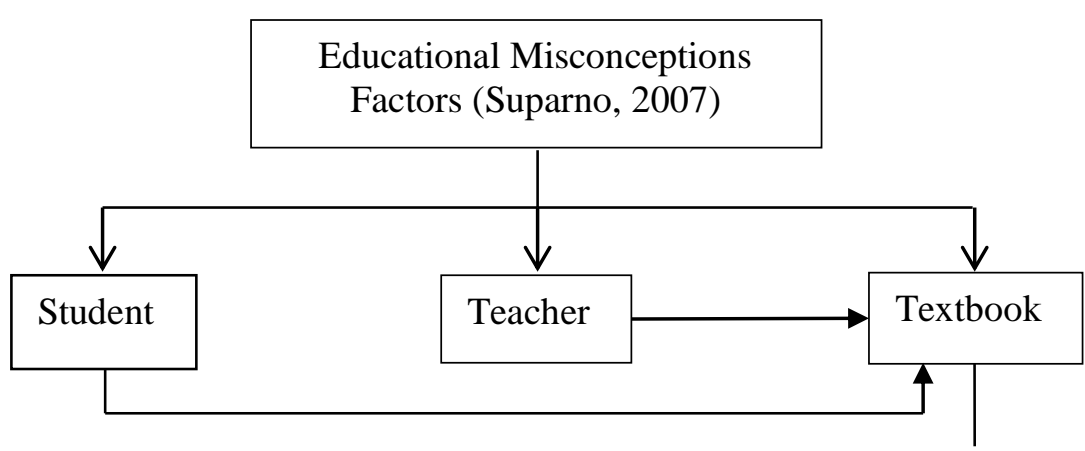

Misconceptions

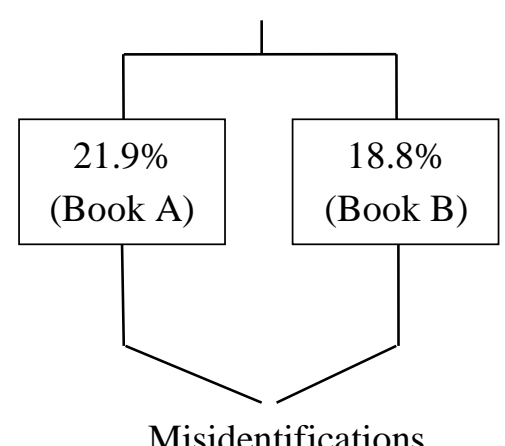

Misidentifications

\section{$\downarrow$}

- The description of the cathode and anode in cell notation

- The symbol of $\mathrm{E}^{\circ}$ value on the potential electrode table

Figure 1 Outline of Research Discovery.

\section{Conclusion and Recommendations}

\section{Conclusion}

In this study, there were a total of 13 misconceptions found in book A and book B in the subject matter of Redox and Electrochemistry. In textbooks A and B each of the three categories of misconceptions are found, namely: oversimplications, overgeneralizations, and misidentifications. The latter category is the category of misconceptions that mostly occur in both textbooks.

Although the authors have tried to propose a perfect research, the results of this study still have several limitations, including: 1) this study only measures the level of misconception of chemical textbooks while there are still many other parameters in measuring the quality of a textbook, for example : the depth of materials, level of readability, and scientific literacy, and 2) the subject matter being analyzed is only Redox and 
Electrochemicalstry material, while there are another subjects being taught in 12th grade high school, such as:

Colligative Properties of Solutions, Chemical Elements, and Elements Radioactive.

\section{Recommendation}

For the teaching community, they should pay more attention to the truth of the textbook concept in their research and report it to educational journals, while for the government, especially the National Education Standards Council (BSNP) and Center for Curriculum and Book keeping (Puskurbuk), a book selection and review process lesson texts must be as strict as research journals.

\section{References}

Adisendjaja, Y. H., and Romlah, O., 2007, Identifikasi Kesalahan dan Miskonsepsi Buku Teks Biologi SMU, Seminar Nasional Pendidikan Biologi, Jurusan Pendidikan Biologi FPMIPA Universitas Pendidikan Indonesia, Makalah, 1-12.

Arifin, Z., 2013, Evaluasi Pembelajaran (Bandung: PT. Remaja Rosdakarya).

Barke, H., Hazari, A., and Yitbarek, S., 2009, Students' Misconceptions and How to Overcome Them. https://doi.org/10.1007/978-3-540-70989-3.

Chattopadhyay, D., 2016, Didaktikogenic Miscocneptions in Physics: An Example. India.

Chang, R., 2008, General Chemistry: The Esential Concepts, 5th International Edition (New York: McGrawHill).

Chiang-Soong, B., and Yager, R. E., 1993, Readability Levels of the Science Textbooks Most Used in Secondary Schools, J. Res. Sci. Teach, 30:339-349.

Chiappetta, E. L., and Fillman, D. A., 2007, Analysis of Five High School Biology Textbooks Used in the United States for Inclusion of the Nature of Science, International Journal of Science Education, 29 (15): 18471868.

Creswell, J. W., 2014, Penelitian Kualitatif dan Desain Riset (Yogyakarta: Pustaka Pelajar).

Hershey, D. R., 2004, Avoid Misconceptions When Teaching about Plants, Date of access: 18/08/2018. http://www.actionbioscience.org/education/hershey.html.

King, C. J. H., 2010, An Analysis of Misconceptions in Science Textbooks: Earth Science in England and Wales. Journal of Science Education, 32 (05): 565-601. DOI: 10.1080/09500690902721681.

McMurry, J., and Fay, R. C., 2010, Chemistry (Upper Saddle River, NJ: Pearson Prentice Hall).

Miles, M. B., and Huberman, A. M., 1992, Analisis Data Kualitatif: Buku Sumber Tentang Metode-Metode Baru (Jakarta: UI Press).

Muslich, M., 2013, KTSP: Pembelajaran Berbasis Kompetensi dan Kontekstual (Jakarta: Bumi Aksara).

Nakhleh, M. B., 1992, Why some students don’t learn chemistry, Journal of Chemistry Education, 69, (3).

Odom, A. L., 1993, Action Potentials \& Biology Textbooks: Accurate, Misconceptions or Avoidance? The American Biology Teacher, 55 (8): 468-472.

Petrucci, R. H., Herring, F. G., Madura, J. D., and Bissonnette, C., 2011, General Chemistry: Principles and Modern Applications, 10th Edition (Toronto: Pearson).

Purwitasari, D., 2012, Analisis Miskonsepsi Buku Sekolah Elektronik (BSE) Kimia SMA Kelas X SMAN 1 Teras Boyolali Materi Hukum-Hukum Dasar Kimia dan Perhitungan Kimia. Skripsi. FKIP Universitas Sebelas Maret, Surakarta.

Rahardjo, S. B., 2015, Kimia Berbasis Eksperimen untuk Kelas XII SMA dan MA Kelompok Peminatan Matematika dan Ilmu Alam (Surakarta: Tiga Serangkai).

Sanger and Greenbowe, 1999, An Analysis of College Chemistry Textbooks As Sources of Misconceptions and Errors in Electrochemistry, Journal of Chemical Education, 76 (6): 853-860. 
Sari, A. R. P., Irwanto, Amelia, R. N., and Nugraheni, S., 2015, Potensi Miskonsepsi Istilah Kimia Pada Buku Ajar Kimia SMA Materi Kesetimbangan Kimia Ditinjau dari Aspek Kebahasaan. Dalam Haerazi, Y.A. Aziz, \& Sudaryanto (Eds.). Prosiding Seminar Nasional Kebijakan Nasional Kebahasaan, hlm. 88-98, Yogyakarta, 14 November 2015: UNY Press.

Silberberg, M. S., 2010, Principles of General Chemistry, 2nd edition (New York City: McGraw-Hill Education).

Stinner, A., 1992, Science textbooks and science teaching: From logic to evidence, Science Education, 76 (1), 1 16.

Sudarmo, U., 2015, Kimia untuk SMA/MA Kelas XII (Jakarta: Penerbit Erlangga).

Suparno, P., 2005, Miskonsepsi dan Perubahan Konsep dalam Pendidikan Kimia. (Yogyakarta: PT. Gramedia).

Weiss, I. R., 1987, Report of the 1985-86 National Survey of Science and Mathematics Education, Center for Education Research and Evaluation, Research Triangle Institute: Research Triangle Park, NC.

Winarni, S., 2010, Perlunya Konsep Kimia Secara Benar Pada Buku Ajar Kimia SMA (The Important of Right Concept in Chemistry Text Book at SMA), Date of access: 15/10/2018. http://www.Jurnal.unsyiah.ac.id/JBE/article/view/1042. 